\title{
STATUS OF EXTERNAL AND INTERNAL LABOR MIGRATION IN UZBEKISTAN
}

\author{
Dusmurodov Obidjon Shomirzayevich
}

Lecturer At The Faculty Of History, National University Of Uzbekistan, Uzbekistan

\section{ABSTRACT}

In recent years, Uzbekistan has been paying serious attention to creating new jobs and ensuring the stability of existing jobs in order to increase employment and economic activity. The main focus is on reducing unemployment, ensuring the employment of graduates of educational institutions entering the labor market for the first time, increasing the employment of vulnerable groups, in particular, women, people with disabilities, convicts, victims of human trafficking, external migration and others. In this regard, the normative legal acts adopted in recent years define a number of important tasks facing the Ministry of Employment and Labor Relations of the Republic of Uzbekistan.

KEYWORDS: - Uzbekistan, migration, migrants, employment, women, human trafficking, law, decision, worker, unemployment, attitude.

\section{INTRODUCTION}

In recent years, modern approaches to solving the problem of migration in developed countries, with special emphasis on the substantiation of the leading trends in the phenomenon of migration. Today, the world's leading research centers have established centers specializing in the study of the impact of international migration on the political and social stability of society and the experience of international and foreign countries in this area. Uzbekistan pays special attention to effective migration policy, improvement of conditions related to external migration processes, and a number of targeted measures are being taken[1,70]. This will help in the main areas of activity of diplomatic missions in the field of work with migrant workers today, in the implementation of measures to ensure the personal safety and social protection of citizens of Uzbekistan abroad.

\section{THE MAIN PART}

Joining many norms of international law, Uzbekistan pays great attention to the protection of human rights, including the rights of migrant workers. In order to further improve the system of external labor migration, radically expand its organizational forms, ensure the protection of labor and social rights of citizens leaving the country to work, adopt a number of regulations to expand the involvement of returning migrant workers in entrepreneurship and labor was made.

In particular, the Resolution of the President of the Republic of Uzbekistan dated July 5, 2018 No 3839 "On additional measures to further improve the system of external labor migration of the Republic of Uzbekistan" defines the main directions of regulation of external labor migration [2,552]. According to this decision, 
CURRENT RESEARCH JOURNAL OF HISTORY 2(6): 67-71, June 2021

DOI: https://doi.org/10.37547/history-crjh-02-06-15

ISSN 2767-472X

(C)2021 Master Journals

\section{Crossref dof 80 Google}

Accepted 24th June, 2021 \& Published 29th June, 2021

from September 1, 2018, legal entities registered in the Republic of Uzbekistan will have the following rights: employment of citizens of the Republic of Uzbekistan abroad on the basis of a license issued by the Ministry of Employment and Labor Relations of the Republic of Uzbekistan; Accreditation in the Ministry of Employment and Labor Relations of the Republic of Uzbekistan, activities to certify the professional qualifications of citizens of the Republic of Uzbekistan going to work abroad, including the acquisition of professional skills and knowledge of foreign languages.

At the same time, in order to improve the registration of citizens of the Republic of Uzbekistan going abroad for work and to conduct research to assess the socio-economic impact of labor migration on society, the Cabinet of Ministers on May 15, 2007 Resolution No. 97 "On improving the registration of citizens of the Republic of Uzbekistan"[3,197]. According to paragraph 4 of the resolution, the Ministry of Employment and Labor Relations will conduct an in-depth special sociological study of labor migration of citizens of Uzbekistan.

Today, in the era of international relations, the world's leading research centers have established centers specializing in the impact of international migration on the political and social stability of society and the experience of international and foreign countries in this area. In particular, research on migration processes is currently being conducted by international organizations such as The Center to Migration Studies of New York (CMS) and The Global Migration Center (GMC).

Many economists around the world have been working on labor migration. In particular, M. Bassand, N.N. Abakumova, V.V. Adamchuk, N.A. Volgin, B.M. Genkin, P.V. Juravlev, S.A. Kartashev, M.G. Kolosnitsyna, N.M. Kuzmina, I.I. Kulintsev, Y.G. Odegov, V.A. Pavlenkov, G.G. Rudenko, A.I.
Rofe, S.Y. Roshchin, B.L. Tokarskiy, G.S. Toniyants and others have focused their research on labor migration issues.

The basic concepts of immigration, emigration, reemigration, "remnants of migration" used in the study of international migration problems were proposed by Nikolaeva[4,62]. The main types of external labor migration of the population have been studied by professor V.A. Iontsev in terms of classification of factors and forms of impact on the country of origin and the country of entry[5,78]. On the scale of the Republic of Uzbekistan can be mentioned the names of R.A. Ubaydullaeva, K.H. Abdurahmanov, L.P. Maksakova, F.U. Mamarasulov, D.N. Rahimova, Z.Y. Khudoiberdiev and others.

According to the Resolution of the Cabinet of Ministers of the Republic of Uzbekistan dated November 12, 2003 "On measures to improve the organization of labor activity of citizens of the Republic of Uzbekistan abroad" Tashkent, Fergana, Nukus, Bukhara and Karshi regional employment bureaus.

Implementation of the Action Strategy of the President of the Republic of Uzbekistan dated February 7, 2017 "On the Strategy for further development of the Republic of Uzbekistan in 2017-2021" January 17, 2019 "On the five priority areas of development of the Republic of Uzbekistan for 2017-2021" Decree of the Government of the Republic of Uzbekistan dated May 24, 2017 "On measures to further improve and increase the effectiveness of state policy in the field of employment", March 5, 2019 "On the state order of employment and creation of new jobs in 2019", July 14, 2018 "On measures to improve and increase the efficiency of work to ensure employment." Adoption of welldeveloped legal and regulatory documents by the Government will play an important role in achieving results in the implementation of work in this area and the emergence of positive 
CURRENT RESEARCH JOURNAL OF HISTORY 2(6): 67-71, June 2021

DOI: https://doi.org/10.37547/history-crjh-02-06-15

ISSN 2767-472X

(C)2021 Master Journals

\section{Crossref dof 80 Google}

Accepted 24th June, 2021 \& Published 29th June, 2021

developments. As a result of effective results in this area, we will be able to achieve great results in the future, making a significant contribution to the economic growth and development of the country.

Globalization is helping to increase human mobility and the migration process in the world. At the same time, population migration is becoming an important factor in economic and social development for developing countries. At the present stage, no country has been left out of migration relations, albeit to one degree or another. The labor force between countries unites the national labor market of international migration into a single market. With the development of globalization, the flow of migration is also accelerating, and a comprehensive solution to this problem is becoming a requirement of the times.

According to the International Organization for Migration (IOM), the total number of international migrants worldwide is about 272 million, two-thirds of whom are labor migrants. It was noted that labor migration plays an important role in world economic relations. According to the data, informal labor migration is increasing worldwide. Such workers are socially and legally unprotected, and in most cases highly skilled professionals have to work as ordinary workers and in some cases are paid several times lower than local workers. In case of disclosure of such illegal activity, the employer and the employee will be subject to large fines, which has become a global problem.

It should be noted that according to the data, migrant workers who do not require higher education and training are sent to construction work. Among migrant workers, there are also those who give up a relatively high level of employment and return before the end of the contract period, which is due to the severity of working conditions. As a result, there is an increase in the share of highly qualified specialists among them.

A number of practical works are being organized in Uzbekistan to study both theoretical and practical aspects of international migration, migrants' rights, and illegal migration from a scientific point of view.

The transformation of the republic as an independent state into an equal member of the world community, a bold step towards building a democratic state governed by the rule of law and a free civil society is a huge socio-historical process. The historical path traversed by the population during the years of independence, the great achievements and milestones achieved, their essence and significance are incomparable. These achievements have been made possible by the prudent policy pursued under the leadership of the First President Islam Karimov and the selfless work of the working people to strengthen independence. An important component of the ongoing reforms in the country is the implementation of the constitutional rights of citizens to work, and large-scale work is being carried out in this area within the basic principles of state policy. One of the key factors in the development of any state is the creation of jobs, employment and thus increase the welfare of the population. The country is paying serious attention to this topical issue on the basis of a programmatic approach and is taking targeted measures. Its purpose is to implement comprehensive and interrelated measures on employment through the mobilization of the potential of the regions and sectors of the economy, to promote the development of effective forms of employment, taking into account demographic and labor market factors.

As the world economy develops and interstate integration ties intensify, so does labor migration. The steady widening of the gap between developed and economically backward 
CURRENT RESEARCH JOURNAL OF HISTORY 2(6): 67-71, June 2021

DOI: https://doi.org/10.37547/history-crjh-02-06-15

ISSN 2767-472X

(C)2021 Master Journals

\section{Crossref dof 80 Google}

Accepted 24th June, 2021 \& Published 29th June, 2021

countries also has a strong impact on accelerating these processes[6,224]. Because labor migration is a special type of migration at the current stage of development of human society, aimed at finding decent work and high incomes, it has become one of the main tools to address the acute problems of employment and wages in less developed countries with difficult economies. Naturally, Uzbekistan, which has achieved political independence, but is faced with the need to address the serious problems of the legacy of the past in socio-economic development, has not been able to stay out of the phenomenon of the twentieth century - labor migration.

Radical changes in Uzbekistan's transition to a market economy have had a profound effect on labor relations in the first place. As a result, in the process of economic reforms, the phenomenon of unemployment, which is inherent in the economic system based on market relations, is an integral part and a constant companion. As a result of objective processes in the economy, thousands and millions of people lost their jobs and lost their source of income. The system of vocational education in the newly independent Republic has not yet adapted to the system of training and retraining of qualified specialists, given the real needs of the rapidly emerging market in the country. As a result, there was a sharp structural imbalance between labor supply and demand in the labor market, and market relations deepened as they were established. All this became a real tragedy for hired workers, whose wages were the sole source of family income, forcing them to find a way out of the crisis, to provide for the family.

Indeed, at the time of Uzbekistan's independence, agriculture was one of the leading sectors of the national economy, with $1 / 3$ of the population employed in socially useful work, and now it has dropped to 26 percent. Considering that the labor force in the rural population increased 1.6 times during this period, we can see that the gap between the supply and demand for labor in the labor market in rural areas has deepened, and we can be sure that rising unemployment is a natural process. In general, the declining number of people employed in agriculture and the decline in the share of the population employed in the total economy are typical of global trends in the world economy, and in our view, these processes will inevitably accelerate in Uzbekistan. The fact that in the economically developed Western countries this figure is around 3-5 percent, and in Germany less than 2 percent is a clear proof of our opinion. This means that a western farmer provides 20 33 people, a German farmer 50 people, and an Uzbek farmer only 4 people.

In the future, as a result of improving the financial situation of farms, the material and technical base of agriculture will develop and the process of reducing employment will accelerate, and under the influence of this factor, the situation in the labor market will worsen.

\section{Conclusion}

In short, first of all, the problem of labor migrants should be considered as one of the most important, central issues of socio-economic development of Uzbekistan in terms of present and future. This issue should be in the constant focus of state leaders, public organizations, scientists, the general public and selfgovernment bodies. In this regard, I believe that a strategy and "road map" of actions aimed at the export of labor of our country should be developed and gradually implemented in practice. According to the analysis, the intensification of external labor migration in Uzbekistan is a matter of time, which is natural in a healthy economy, which provides a large balance in the labor market. 
CURRENT RESEARCH JOURNAL OF HISTORY 2(6): 67-71, June 2021

DOI: https://doi.org/10.37547/history-crjh-02-06-15

ISSN 2767-472X

(C)2021 Master Journals

Crossref do: 81 Google

Accepted 24th June, 2021 \& Published 29th June, 2021

\section{REFERENCES}

1. Decree of the President of the Republic of Uzbekistan No. PF-4947 of February 7, 2017 "On the Strategy of Actions for the Further Development of the Republic of Uzbekistan" // Collection of Legislation of the Republic of Uzbekistan, 2017, No. 6, Article 70.

2. Collection of Legislation of the Republic of Uzbekistan, July 9, 2018, No. 27, Article 552.

3. Collection of Legislation of the Republic of Uzbekistan, 2007, No. 19-20, Article 197.

4. Iontsev V.A. International population migration: theory and history of study. - M., 2005. - P. 62.

5. Abdurahmonov Q.X. Labor economics. Textbook. Toshkent, 2009. - P. 78.

6. Muydinov D.N. The impact of migration processes on the stability of Europe (in Germany's case) // International Journal of Political Science and Development. ISSN: 2360-784. X Volume, 06 Issue 07 October 2018. - P 219-224.

7. Ochildiev, F. (2021). THE INFLOW OF RUSSIAN CAPITAL AND INDUSTRY INTO THE BUKHARA EMIRATE IN THE LATE 19TH AND EARLY 20TH CENTURIES. CURRENT RESEARCH JOURNAL OF HISTORY (2767472X), 2(06), 20-26.

8. Очилдиев, Ф. (2021). XIX асрнинг иккинчи ярми-XX аср бошларида Сурхон вохаси бекликларининг мамурий бўлиниши ва бошқарув тизими. Общество и инновации, 2(4/S), 387-397.

9. Ochildiev, F. (2021). Cotton Production Development In Bukhara Emirate During The Late XIX-Early XX Centuries. The American
Journal of Social Science and Education Innovations, 3(02), 119-125.

10. Ochildiev, F., \& Kuyliev, R. (2021). Location of the population and ethnic composition of surkhan oasis in the late xix and early $\mathrm{xx}$ centuries. ACADEMICIA: An International Multidisciplinary Research Journal, 11(3), 1062-1069.

11. Очилдиев, Ф. Б., \& Тогаев, Ж. Э. (2015). ЗАМЕТКИ О СИСТЕМЕ МЕСТНОГО УПРАВЛЕНИЯ В БУХАРСКОМ ЭМИРАТЕ В СЕРЕДИНЕ ХІХ-НАЧАЛЕ ХХ ВЕКА. Национальная Ассоциация Ученых, (2-9), 47-50.

12. Ochildiev, F. B. (2008). Socio-political and economic changes in the principalities of the Surkhandarya oasis.

13. Parmanov, S. (2021). Formation of The Medieval Cities In The Kesh Oasis. Journal of Contemporary Issues in Business and Government, 27(1), 1386-1403.

14. Muhamedov, Y. (2021). Reforms of The Western Turkish Khanate In The Chach Administration. The American Journal of Social Science and Education Innovations, 3(02), 133-140. 